\title{
R. v. LUXTON AND FIRST DEGREE MURDER IN CANADA: A "CONSTRUCTIVE" CRITICISM
}

\section{CRAIG BELL ${ }^{*}$}

\section{INTRODUCTION}

In 1976, as a political compromise in the formal abolition of the death penalty, Parliament drew a distinction between first and second degree murder. Pursuant to what is now s. 231 of the Criminal Code,' although both first and second degree murder carry a mandatory sentence of life imprisonment, one convicted of first degree murder normally cannot be considered for parole until 25 years have elapsed. Section $231(5)^{2}$ establishes an automatic first degree murder category in which a murder in the course of a few listed offences will result in a verdict of first degree murder. The constructive first degree murder rule is an anomalous by-product of a haphazard legislative history. ${ }^{3}$

On 13th September 1990, the Supreme Court of Canada handed down a number of decisions, effectively re-writing Canada's murder laws, by making sweeping pronouncements on the fault required under the Canadian Charter of Rights and Freedoms $s^{4}$ for the crimes of murder and attempted murder, and the doctrine of common intent. The Court also ruled, in its decision in the case of $R$. v. Luxton, ${ }^{5}$ that the legislation creating constructive first degree murder was constitutional. This commentary will review the content and history of the legislation, the logic and arguments of the decision in Luxton and the effect of the decision on the state of the law in Canada, including the limited application of Luxton in subsequent cases.

\section{THE IMPUGNED LEGISLATION}

There are two problems raised by the existing Criminal Code which invite scrutiny under the Charter: first, the existence of a category of "constructive" first degree murder, and secondly, the automatic mandatory sentences imposed as a penalty for the crime of murder.

In Canada, there is only one crime of murder. Once the jury finds the accused guilty of murder under s. 229 or s. 230, it must then go on to classify the murder as being first or second degree, under s. 231 , for sentencing purposes. This is a vital process as first degree murder has a minimum sentence of twenty five years before parole

Currently clerking at the Alberta Court of Appeal, Calgary.

am. R.S.C. 1985, c. 27 (1st Supp.), ss. 7(2)(b), 35, 40(2).

[en.1974-75-76, c. 105, s. 4; since re-en. 1980-81-82-83, c. 125, s. 16; am. 1985, c. 19, s. 41(2)].

D. Stuart, "Further Progress on the Constitutional Requirement of Fault, But Stigma is Not Enough" 79 C.R. (3d) 247 at 250.

4. Part I of the Constitution Act, 1982, being Schedule B to the Canada Act 1982 (U.K.), 1982, c. 11.

5. [1990] 2 S.C.R. 711, 79 C.R. (3d) 193, [1990] 6 W.W.R. 137, 76 Alta L.R. (2d) 43, 112 N.R. 193, 58 C.C.C. (3d) 449 , 111 A.R. 161. 
eligibility whereas second degree murder has, as a minimum, parole eligibility after ten years. ${ }^{6}$

The Code sets out certain types of murders (which are deemed to be more heinous or more in need of deterrence) and these are subject to the harsher penalties for first degree murder. The most widely used provisions are those regarding planned and deliberate murder and those dealing with the killing of police officers or prison guards. At one time the test for distinguishing capital and non-capital murder, the phrase "planned and deliberate" is now one of designation to first degree murder. The second word deliberate - is defined by contradistinction to "impulsive".?

Section 231(5) creates a "constructive" first degree murder. Constructive murders are not premeditated; many murders occurring through 231(5) could be impulsive. Section 231(5) works to automatically elevate some second degree murders into first degree murders, depending on the underlying offence involved. Those offences are hijacking, various forms of sexual assault, kidnapping and forcible confinement, and hostage-taking. The list is very much shorter than the list of offences formally included in the constructive murder rule of s. 230. It is apparent that not all offences were meant to be included. For example, a murder occurring in the course of the most common s. 230 offence, robbery, would not automatically lead to a first degree murder conviction. ${ }^{8}$

\section{THE IMPORTANCE OF THE PENALTY}

Of the various purposes of punishment in criminal law (propitiation of the victim, expiation of the accused, reform, deterrence, rehabilitation), the sentence for a convicted murderer concentrates on only one: deterrence. The way a society deals with its murderers could be said to be indicative of the way it treats all its wrongdoers. The penalty for murder is a figurehead, symbolic of the other punishments in the criminal justice system.

Usually the reformer of the criminal law can concentrate on the substantive law without paying attention to penalty. This cannot be said regarding murder provisions. The view of murder which emphasizes the uniqueness of that crime has become associated with a fixed penalty. In Canada, this is mandatory life imprisonment. The argument favouring its retention focuses primarily on the symbolic importance of recognizing this especially serious crime. The alternative view is that in murder, as in other crimes, the penalty should be discretionary and variable from case to case depending on specific circumstances. ${ }^{9}$

The entire structure of the law of homicide is heavily influenced by decisions about penalty. Indeed, the law of murder as it has developed to this point suggests the lawmakers had been enjoined to "let the crime fit the punishment" rather than the other $\therefore$

I. Grant \& W. MacKay, "Constructive Murder and the Charter: In Search of Principle" (1987) 25 Alta. L. Rev. 129 at 137.

Ibid.

Ibid. at 138.

P. MacKinnon, "Two Views of Murder" (1985) 63 Can. Bar Rev. 130 at 141. 
way around. This is illustrated by the special defence of provocation, which relates only to murder. It is because murder has a mandatory penalty that such special defences are allowed. ${ }^{10}$

The sentencing provision for first degree murder, s. 742(a) of the Criminal Code," was a concession granted to appease those who were against abolition of the death penalty. When capital punishment was abolished in 1976, the twenty five year minimum before parole eligibility was implemented in its place. The sentencing judge under $\mathrm{s} .742$ has no discretion whatsoever to tailor the sentence to fit the crime. The issue arising from the operation of s. 231(5) is that it takes a large number of cases out of the judge's discretion by automatically rendering them first degree murder. ${ }^{12}$

\section{THE HISTORY OF THE LEGISLATION}

\section{A. THE LEGISLATIVE BACKGROUND}

The creation of the two categories of murder, first and second degree, and the current sentences for these offences, evolved from the debate over capital punishment which occupied Parliament and the Canadian public for over twenty years. In 1956, a joint committee of the Senate and the House of Commons recommended the retention of capital punishment but suggested the division of the offence of murder into capital and noncapital categories. ${ }^{13}$

In 1961, the Criminal Code was amended to provide for capital murder which would be punishable by the death penalty, unless the accused was under the age of 18 years. ${ }^{14}$ Capital murder was defined as "planned and deliberate", occurring during certain crimes of violence, or the murder of a police or corrections officer while on duty. All other murder was characterized as noncapital and was punishable by life imprisonment. ${ }^{15}$

This regime continued in force until 1967 when the Code was again amended to limit capital murder to those cases where the accused participated in the killing of a police officer or prison guard. ${ }^{16}$ From 29 December 1967 to 29 December 1972, under Chapter 15 of the Statutes of Canada, murder was limited to cases where the accused, by his own act, caused or assisted in causing the death of a police officer acting in the course of his duties. This Act was to continue in force for 5 years, ${ }^{17}$ but it was extended for a further five years in $1972 .{ }^{18}$ During the semi-moratorium, persons who had been sentenced to death but whose sentence had been commuted could not be released without the approval

Ibid.

R.S.C. 1985 , c. C-46.

Supra note 6 at 139.

A. Manson, "The Easy Acceptance of Long Term Confinement in Canada" 79 C.R.(3d) 265.

An Act to Amend the Criminal Code (Capital Murder), S.C. 1960-61, c. 44, s. 1.

Government of Canada, Department of Justice, Questions and Answers Relating to the Capital Punishment Issue (Ottawa: Queen's Printer, 1972) at 20.

An Act to Amend the Criminal Code, S.C. 1967-68, c. 15, s. 1.

Supra note 15 at 20.

1972: Criminal Law Amendment Act (Capital Punishment), S.C. 1973-74, c. 38, s. 10. 
of the Governor General. This semi-moratorium on capital punishment did not extend to the murder of police or prison guards. Persons who were sentenced to life imprisonment for murder could be released after 10 years. This was the statutory sentencing background against which Parliament resumed the debate on capital punishment in 1976. ${ }^{19}$

The debate regarding the final and complete abolition of the death penalty raged in the House of Commons over several years. Battle lines were clearly drawn. Some retentionist members suggested that the list of capital offences be expanded to include pickpocketing and various other economic matters. ${ }^{20}$ In particular, aircraft hijackings and terrorism commanded much attention in the early 1970's and the government of the day felt a great deal of pressure in dealing with the problem. ${ }^{21}$

\section{B. THE BIRTH OF WHAT IS NOW SECTION 231(5)}

It was within such an adversarial environment that the constructive murder clause of s. 231 was created. In the 1973 debate of Bill C-2, which failed to pass, amendments were suggested to ensure that persons causing death while committing rape, kidnapping or hijacking should receive the maximum penalty available. ${ }^{22}$ These suggestions were implemented into the next draft legislation.

The Criminal Law Amendment Act, 1976 was designed to "come to grips with the increasing incidence of crime in Canadian society and to meet the need the public feels for a greater measure of protection". Concerns noted by the government in preparing the legislation, which was concerned primarily with the abolition of the death penalty, focused on items which were frequently in the news at the time: disturbances and hostage taking in penitentiaries, airplane hijackings, and a few spectacular crimes (usually involving sexual assaults) committed by persons released mandatorily from federal institutions, by parolees and by offenders on temporary absence from prison. ${ }^{23}$ The solution: add these crimes to a list which would automatically make death in commission of them first degree murder.

\section{THE BIRTH OF WHAT IS NOW SECTION 742}

In the Standing Committee on Justice and Legal Affairs, a clause by clause consideration of the new bill took place. In that committee, statistics were tabled to show the Canadian experience with life imprisonment, as well as terms applied in other countries. With all the data, both Canadian and comparative, pointing to a period of between 10 and 15 years, the proposed legislation went forward providing for a minimum term for first degree murder of 25 years. The reason: political expedience. Mr. Warren Allmand, the Solicitor General who had fronted the struggle to abolish capital punishment,

20. House of Commons Debares, (24 May 1973) at 4078.

21. House of Commons Debates, (4 March 1974) at 106.

22. Supra note 20 at 4078.

23. Government of Canada, Department of Justice, The Highlights of the Peace and Security Program - The Criminal Law Amendment Act, 1976 (Ottawa: Queen's Printer, 1976) at 1. 
was told by the Canadian Association of Police Chiefs, who supported the death penalty, that only a minimum sentence as severe as 25 years could be considered as a reasonable alternative to hanging. ${ }^{24}$

The legislation developed was clearly a compromise which few were happy with. Members recognized the arbitrary distinctions between first and second degree murder, and the fact that robbery was not included in the list of crimes under 231(5). ${ }^{25}$ Also questioned were the mandatory minimum sentences, which were attacked on the basis of lessening chances of rehabilitation. ${ }^{26}$

Since the passionate and partisan discussions of 1976 focused on the fundamental issue of the legitimacy of capital punishment, little attention was paid to the elements of proposed alternatives, ${ }^{27}$ and any discussion regarding sentencing centred on the deterrent effect any penalty would have.

\section{HISTORY SINCE PASSAGE}

\section{A. IN PARLIAMENT}

Despite the problems with the murder legislation, it has not attracted a groundswell of reforming zeal amongst legislators. This is understandable as elections are rarely fought on the basis of reform of the Criminal Code. Also, convicted murderers do not comprise a particularly powerful political lobby. ${ }^{28}$

On the other hand, there is a large and vocal group of people in this country who favour a return to capital punishment. Every sitting of Parliament brings forward several private member's bills calling for the government to reinstate the death penalty. A vote for restoration of capital punishment was held in the House of Commons as recently as June 30,1987 , with 127 in favour of bringing back the penalty, and 148 against. Several very active lobby groups continue to push for a return of capital punishment and, as a fall back position, life sentences without parole. ${ }^{29}$

\section{B. JUDICIAL CONSIDERATION}

Subsequent developments, instead of reducing the overreach of the "constructive" provision, have broadened its scope. In $R$. v. Farrant, ${ }^{30}$ a pre-Charter case, the Supreme Court of Canada recognized the existence of an organizing principle of "unlawful domination over the person" which defined what murders should be elevated in the

Supra note 13 at 267.

House of Commons Debates, (7 June 1976) at 14229.

lbid.

Supra note 13 at 266.

S. Usprich, "Vaillancourt: A Criminal Reports Forum - Felony Murder and Far Beyond" 60 C.R. (3d) 332 at 333.

C. Jayewardene, After Abolition of the Death Penalty (Ottawa: Crimcare, 1989) at 16.

[1983] 1 S.C.R. 124, 32 C.R. (3d) 289, [1983] 3 W.W.R. 171, 4 C.C.C. (3d) 354, 147 D.L.R. (3d)

511, 21 Sask. R. 271, 46 N.R. 337 [hereinafter Farrant cited to S.C.R.]. 
judicial definition of wrongful confinement for first degree murder. Commenting on the wide definition, Dickson J., as he then was, said: ${ }^{31}$

The rule may seem harsh but it is not the function of this Court to consider the policy of legislation validly enacted. So long as the section continues in our Criminal Code it must be given effect in accordance with its terms.

The ambit of s. 231(5) was extended in $R$. v. Pare, a post-Charter case, where the Supreme Court of Canada recognized a sexual assault followed by a killing as a "continuing transaction" in which "unlawful domination" existed, to ensure a conviction for first degree murder. Despite the date, Charter issues were not litigated.

\section{SECTION 231(5) AND THE CHARTER}

There are two problems raised by the existing Criminal Code provisions which would invite the scrutiny of the reformer: first, the existence of a category of "constructive" first degree murder, and secondly, the automatic mandatory sentences imposed on the crime of murder. ${ }^{33}$

Given the reluctance of Parliament to re-examine the legislation, judicial review was required to determine if the provisions unjustifiably conflicted with the rights and freedoms enshrined in the Canadian Charter of Rights and Freedoms. ${ }^{34}$ This is the reason why the appellant in $R$. v. Luxton was granted leave to appeal to the Supreme Court of Canada.

\section{THE CASE DECISION(S)}

On 13th September 1990 the Supreme Court of Canada, in five concurrently-released rulings, redefined criminal intent and reclassified unintentional killings. The decisions released on that date were $R$. v. Martineau ${ }^{35}$ and $R$. v. Luxton from Alberta, $R$. v. Rodney ${ }^{36}$ and $R$. v. Arkell ${ }^{37}$ from B.C., and $R$. v. Logan and Johnson ${ }^{38}$ from Ontario. In the series of judgments, the court decided, among other items:

\footnotetext{
31. Ibid. at 130.

32. [1987] 2 S.C.R. 618, 60 C.R. (3d) 346, 38 C.C.C. (3d) 97, 45 D.L.R. (4th) 546, 80 N.R. 272, 11 Q.A.C. 1.

33. Supra note 6 at 137.

34. Supra note 28 at 333 .

35. [1990] 2 S.C.R. 633, 79 C.R. (3d) 129, [1990] 6 W.W.R. 97, 76 Alta. L.R. (2d) 1, 109 A.R. 321, 50 C.R.R. 110, 58 C.C.C. (3d) 353,112 N.R. 83 [hereinafter Martineau cited to S.C.R.].

36. [1990] 2 S.C.R. 687, 79 C.R. (3d) 187, 49 B.C.L.R. (2d) 14, 58 C.C.C. (3d) 408, 112 N.R. 167, 50 C.R.R. 169.

37. [1990] 2 S.C.R. 695, 6 W.W.R. 180, 49 B.C.L.R. (2d) 1, 59 C.C.C. (3d) 65, 112 N.R. 175, 50 C.R.R. 193, 79 C.R. (3d) 207.

38. [1990] 2 S.C.R. 731, 79 C.R. (3d) 169, 58 C.C.C. (3d) 391, 74 O.R. (2d) 644, 112 N.R. 144, 73 D.L.R. (4th) 40, 41 O.A.C. 330, 50 C.R.R. 152.
} 
1. Objective mens rea is not sufficient to sustain a murder conviction. Therefore, constructive murder - an unintended homicide occurring during the commission of another crime - violates the principles of fundamental justice. The provisions infringed ss. 7 and 11(d) of the Charter and were not saved by s. 1. Thus, the constructive murder provisions of the Criminal Code, s. 230 (in its entirety) and s. 229(c), are unconstitutional. Martineau was the key case in this ruling, with the Court ruling 6-1.

2. However, "constructive first degree murder" - the classification of certain murders as first degree murders, under s. 231(5) - did not offend the rights to fundamental justice and did not constitute arbitrary detention or cruel and unusual punishment, and as such did not violate ss. 7, 9 or 12 of the Charter. Further, the Court held the 25 year minimum sentence was appropriate. Luxton was the keynote case in this ruling, with the Court being unanimous in the result.

The Supreme Court of Canada has surgically removed "constructive murder" from the determination of murder, but has retained "constructive first degree murder". This result seems out of place, given the Court's past application of the Charter to the law.

Would-be reformers to the law on murder recognize there are two ways to observe it. As commented on above, one view is to perceive murder as a unique crime; the second view is to encourage an integrated approach to all culpable homicides, reflected in terminology, definition, defences and penalties. ${ }^{39}$ The Supreme Court of Canada, through its decisions in $R$. v. Vaillancourt $t^{40}$ and now Martineau, appeared to be developing a reform and simplification of the law regarding murder, following this second, more principled approach. In Luxton, they seem to draw the line in this respect, unwilling to extend the same logic to the determination of first degree murder.

The Supreme Court of Canada was unanimous: s. 231(5) has withstood Charter scrutiny. But it is submitted that the reasoning of the Court is not persuasive. This is the subject of the commentary below.

\section{FUNDAMENTAL JUSTICE AND s. 231(5)}

\section{A. PROPORTIONALITY OF FAULT}

The major defect of s. $231(5)$ is that the constructive first degree murder provision automatically classifies murder during the attempt or commission of forcible confinement as equal in seriousness to the other forms of first-degree murder, most notably planned and deliberate murder. Whether planned and deliberate or not, murder is first degree when committed in the course of certain listed offences. ${ }^{41}$ 
Theories of retributive justice are based on the notion that the degree of retribution, or punishment, should reflect the moral blameworthiness of the accused. ${ }^{42}$ The constitutional imperative of fault is offended where a conviction is permitted without proof of a guilty mind. Canadian constitutional analysis of the criminal law has extended the fault requirement beyond the "morally innocent" notion developed in Reference re 94(2) B.C. Motor Vehicle Act $t^{43}$ to entrench proportionate blameworthiness as a constitutional standard of substantive responsibility, as per Vaillancourt.

The rationale of constructive murder provisions is that "one who commits a felony is a bad person, with a bad state of mind, who has caused a bad result." At a base level, the only value to constructive murder is prosecutorial expedience. This expedience usually manifests itself in how the provision is applied. In respect to s. 231(5)(e), the results are graphic. "Forcible confinement" is the criminal equivalent of the tort of false imprisonment, and had been the subject of only 3 reported cases in Canada between 1869 and 1975. Yet, in the application of s. 231(5)(e), it served as the underlying element in 5 murder convictions between 1976 and 1983. ${ }^{44}$ Such expedience is an insufficient basis on which to justify the rule. ${ }^{45}$

The fatal flaw of the constructive murder rules struck down in Vaillancourt and Martineau is that they made a killing in the course of listed offences automatically murder, without any inquiry into culpability respecting death. So too with the felony first degree murder category. Murder in the course of any of the offences listed in s. 231(5) may often be serious enough to require an extra penalty, but this is not always the case. ${ }^{46}$

The Supreme Court of Canada has often recognized that there is a higher level of moral culpability associated with first degree murder. In $R$. v. Wallen, ${ }^{47}$ the Court, having regard to the serious consequences on the accused, found it was imperative that the jury be explicitly and clearly instructed on the fact that it requires a lesser degree of drunkenness to negative "planning and deliberation" than it would to negative mere intent to murder, due to the higher thought process involved.

In Luxton, Lamer C.J.C. summarizes the Court's position regarding the first degree murder rule as: ${ }^{48}$

Parliament has chosen, once it has been proven that an offender has committed murder, to classify certain of those murders as first degree. Murders that are done while committing offences which involve the

42. Supra note 6 at 153.

43. [1985] 2 S.C.R. 486, [1986] I W.W.R. 481 (sub nom. Ref. re s. 94(2) of Motor Vehicle Act), 69 B.C.L.R. 145, 48 C.R. (3d) 289, 36 M.V.R. 240, 23 C.C.C. (3d) 289, 24 D.L.R. (4th) 536, 18 C.R.R. 30, 63 N.R. 266 [hereinafter Ref. re. s. 94(2) cited to C.R.].

W. MacLaughlan, "The Explosive Combination of Forcible Confinement and Constructive Murder: What Are its Proper Confines?" (1983) 21 Osgoode Hall L.J. 701 at 702-703.

4s. Supra note 6 at 153.

t6. D. Stuart, "Annotation - R. v. Pare" (1987) 60 C.R. 346 at 347.

47. [1990] 1 S.C.R. 827, 3 W.W.R. 481, 73 Alta. L.R. (2d) 30, 54 C.C.C. (3d) 383, 107 N.R. 50, 107

A.R. 114, 75 C.R. (3d) 328.

48. Supra, note 5 at 721-22. 
illegal domination of the victim by the offender have been classified as first degree murder. Forcible confinement is one of those offences involving illegal domination. The added element of forcible confinement in the context of commission of a murder, markedly enhances the moral blameworthiness of an offender. Indeed, forcible confinement is punishable by up to ten years in prison. The decision of Parliament to elevate murders done while the offender commits forcible confinement to the level of first degree murder is consonant with the principle of proportionality between the blameworthiness of the offender and the punishment.

This "them's the rules" approach is out of character for the Court. Vaillancourt powerfully asserted a constitutional imperative of fault being proportionally related to the severity of the penalty. It is curious that the Supreme Court, which has striven to assert a subjective mens rea as the fault requirement of serious offences, both before and after the enactment of the Charter, even when not expressly required, has chosen to ignore it in deciding whether a particular murder falls within the most serious penalty category of first degree murder. Given their dubious history, a literal approach to the interpretation of the first degree murder categories seems misplaced. Surely the fundamental requirement of fault is applicable. ${ }^{49}$

\section{B. IS THE ORGANIZING PRINCIPLE RATIONAL?}

With respect to whether s. 231(5)(e) is inconsistent with s. 7 of the Charter, Lamer C.J.C. concludes that the inclusion of certain offences in s. 231 is guided by the "organizing principle" identified by the Court in Pare and thereby is neither arbitrary nor irrational and therefore does not infringe upon s. 7.

The Law Reform Commission of Canada has commented on the lack of rationale in the law. It is curious that the list in s. 231(5) is considerably shorter than that given in s. 230 which made killing murder if done in the commission of certain specified offences. Inspection and comparison of the two lists, however, reveals no organizing principle in either of them and no rationale for the difference between them. ${ }^{50}$

The Commission, in its criticism, noted that hijack killings are wrongly put on a different footing than other acts of terrorism (for example, those done on ships and trains). This further illustrates that the law expressed in s. 231 has not been based on a welldetermined principle or rationale, but merely on the concerns of the politicians of the day.

The choice of offences under s. 231(5) is largely arbitrary. A forcible confinement, for example, can range from a terrorist hostage taking to a situation such as Farrant where a seventeen year old boy took a gun to force his girlfriend to talk to him. The range of acts that could be classified as "forcible confinement" is incredibly broad, covering any restraint of liberty, as the application of the provision in practice indicates that actual force is not required. In theory, forcible confinement could extend as far as a domestic quarrel in the confines of the family kitchen. ${ }^{51}$ 
Similarly, it is difficult to see how the offences listed in s. 231(5) are inherently more dangerous than those in s. 230 which are not included in s. 231(5). Is a forcible confinement, for example, always more dangerous than an armed robbery or arson? $?^{52}$ The sentences imposed for the underlying offences themselves certainly do not reflect it. Lamer C.J.C. notes, as above, that forcible confinement markedly enhances the moral blameworthiness of the offender, and this is reflected in the fact that forcible confinement is punishable by up to ten years in prison. But robbery, which is not included in s. 231(5), has a maximum of life imprisonment, whereas the sexual assault provisions of $s$. 246.1 have a maximum sentence of only 10 years. Break and entry also carries a maximum of life imprisonment, and yet is not included in either s. 230 or s. 231(5). The relationship between classification and moral blameworthiness of the accused lacks a rational foundation. ${ }^{53}$

In Pare, as applied in Luxton, the Supreme Court of Canada expressly rejected the view of the Law Reform Commission of Canada that there was no organizing principle in the list of offences under s. 231(5), and that there is no rationale for a shorter list under $\mathrm{s}$. 231(5) than under s. 230. The sentencing scheme in s. 231(5), as explained in Pare, classifies murders as more serious where committed while the offender was exploiting a position of power through illegal domination of a victim. ${ }^{54}$ According to the Court, the relationship between the sentence classification and the moral blameworthiness of the offender clearly exists, as the section comes into play only where murder has been proven beyond a reasonable doubt.

But the classification system itself is not defensible. For example, the offences of robbery and assault on a police office are contained in s. 230, but not in s. 231(5). Surely these offences may also involve "unlawful domination over the person" as well. ${ }^{\text {s5 }}$ In fact, with regards to robbery, under Criminal Code s. 343, domination of another by force or threats is an element of the offence. ${ }^{56}$

Thus, it cannot possibly be said that the list of murders under s. 231 includes all murders involving unlawful domination over the person. All murders involve some domination. The classification was and is irrational, and reflects the haphazard debates which spawned it. Given the above, and the section's questionable roots, the Supreme Court of Canada should have critically reviewed the classification and declared the provision unconstitutional. ${ }^{57}$

52. Supra note 6 at 138.

53. Ibid.

s4. Supra note 46 at 347.

s5. Ibid.

s6. R. v. Strong (1990), 2 C.R. (4th) 239 at 251,60 C.C.C. (3d) 516, 111 A.R. 12 (C.A.) [hereinafter Strong cited to C.R.].

57. Supra note 3 at 251. 


\section{IS THE SENTENCE PROPORTIONAL?}

The next issue before the Court required an examination of the combined effect of $s$. 231(5)(e) and s. 742 of the Code on the rights guaranteed by s. 7 of the Charter. The argument was that the principles of fundamental justice require that differing degrees of moral blameworthiness in different offences be reflected in differential sentences, and that sentencing be individualized. A just sentencing system contains a gradation of punishments differentiated according to the malignity of offences and therefore sentencing should be graduated as well.

The argument against a mandatory penalty is that the labels of criminal law are crude. The range of behaviour contemplated by any one of these labels is wide. This is as true for murder as it is for robbery or for assault. Is the same punishment equally appropriate to all possible states of behaviour caught under s. 231(5) $?^{58}$

Lamer C.J.C., without confirming that s. 7 includes constitutional requirements of proportionate and individualized sentences, summarizes the Court's position, noting alteration for Criminal Code renumbering: ${ }^{59}$

In my view the combination of s. 231(5)(e) and s. 742 clearly demonstrates a proportionality between the moral turpitude of the offender and the malignity of the offence, and moreover it is in accord with the other objectives of a system of sentencing identified by La Forest J. in Lyons.

Lamer C.J.C. borrows from $R$. v. Lyons, ${ }^{60}$ where La Forest J. considered the dangerous offender designation in the Code, and said the following in respect of the relationship between sentencing and its objectives: ${ }^{61}$

I accordingly agree with the respondent's submission that it cannot be considered a violation of fundamental justice for Parliament to identify those offenders who, in the interests of protecting the public, ought to be sentenced according to considerations which are not entirely reactive or based on a "just deserts" rationale. The imposition of a sentence which "is partly punitive but is mainly imposed for the protection of the public" ... seems to me to accord with the fundamental purpose of the criminal law generally, and of sentencing in particular, namely, the protection of society. In a rational system of sentencing, the respective importance of prevention, deterrence, retribution and rehabilitation will vary according to the nature of the crime and the circumstances of the offender.

But does the sentencing system of the Criminal Code live up to this test? The sole consideration upon which the murder distinctions and penalties were developed was and is deterrence. As noted above the penalties for murder do not seem to place much emphasis on retribution or rehabilitation of the offender. What of the common sense assertion that a life sentence removes all incentive for rehabilitation? Can there be any 
allowance for judicial discretion where there is a mandatory life sentence and a minimum parole period?

Treating morally different acts as if they are the same, by imposing the same penalty, is to violate the principle of fundamental justice that like cases are to be treated alike, and those different in relevant respects are to be treated differently. This is the concept of proportionate blameworthiness which first arises in Re s. 94(2) B.C. Motor Vehicle Reference and later, through the medium of s. 12 , in $R$. v. Smith. ${ }^{62}$ Punishment by imprisonment is not an exact science. There is no moral calculus by which one can determine the number of years warranted as a response to a particular level of moral culpability. Prison sentences only express degrees of moral blameworthiness in the comparative context of a sentencing regime. Sentences are deemed appropriate not in an absolute sense but relative to other crimes and sentences. Assuming that murder is the most serious offence, it should, ignoring other objectives of criminal law, lead to the longest sentence. Murders which occur in different circumstances may vary in a morally relevant way, and demand different treatment. The mandatory imposition of the same minimum penalty prevents this relevant difference from being reflected. ${ }^{63}$

\section{THE "ARBITRARY" ARGUMENT}

The next argument placed before the Court was that the combination of s. 231(5)(e) and s. 742 contravened s. 9 of the Charter because the imposition of a mandatory term of imprisonment for an offence that encompasses a range of moral turpitude was, in effect, arbitrary.

While Lamer C.J.C. allowed that it was true that the definition of forcible confinement adopted by the courts allowed for varying circumstances in each individual case, this alone was not a sign of arbitrariness. He said that since the offence clearly fell under the rubric of the organizing principle enunciated by the Court in Pare, namely that of the "illegal domination", the decision of Parliament to attach a minimum twenty-five year sentence without eligibility for parole in cases of first degree murder cannot be said to be arbitrary within the meaning of s. 9 of the Charter. He stated: ${ }^{64}$

\footnotetext{
The incarceration is statutorily authorized, it narrowly defines a class of offenders with respect to whom the punishment will be invoked and it prescribes quite specifically the conditions under which an offender may be found guilty of first degree murder. Further, the policy decision of Parliament to classify these murders as first degree murders accords with the broader objectives of a sentencing scheme. The elevation of murder while committing a forcible confinement to first degree reflects a societal denunciation of those offenders who choose to exploit their position of dominance and power to the point of murder.
}

Does statutory authorization make incarceration valid? As above, is the class of criminal behaviour labelled as "forcible confinement" really that narrow? The same 
arguments could have been used to support any impugned criminal statute, including the constructive murder provisions struck down in Vaillancourt and Martineau.

\section{A CRUEL AND UNUSUAL ARGUMENT}

The final Charter argument raised by the appellant was that the combined effect of $s$. 231(5) and s. 742 contravened s. 12 of the Charter, which protects individuals against cruel and unusual punishment, by dealing with relationships between the effects of (and reasons for) punishment.

In $R$. v. Smith, ${ }^{65}$ the seven year mandatory penalty for importing narcotics was found to violate $\mathrm{s} .12$ because it would lead, in some cases, to a punishment which was grossly disproportionate, having regard to the offence and the offender. ${ }^{66}$ Smith is the definitive case regarding the phrase "cruel and unusual punishment". It is disappointing that the Court, while claiming to adopt the logic of that case, does not apply it, either in letter or in spirit.

\section{A. THE CHOICE OF TEST}

In Smith, the Court confirmed that s. 12 represents a "compendious expression of a norm" which prohibits grossly disproportionate punishments. The two judgments rendered in Smith offer various tests which might produce a finding of cruel and unusual punishment: Lamer J., as he then was, discusses nine different tests, and McIntyre J. synthesizes these into three categories. ${ }^{67}$

One test proposed by Lamer J., as he then was, is whether the punishment outrages standards of decency. In Luxton, this test becomes the sole determinant, the single analytical tool, in validating the penalty of long term confinement. ${ }^{68}$ The other applicable tests are conveniently not mentioned. Lamer C.J.C. says of Smith: ${ }^{69}$

That case held that the criterion to be applied in order to determine whether a punishment is cruel and unusual is whether the punishment is so excessive as to outrage standards of decency.

\section{B. THE APPLICATION OF THE TEST}

He then applies this single criterion borrowed from Smith: ${ }^{70}$

These sections provide for punishment of the most serious crime in our criminal law, that of first degree murder. This is a crime that carries with it the most serious level of moral blameworthiness, namely subjective foresight of death. The penalty is severe and deservedly so. The minimum twenty-five years

Supra note 62.

Supra, note 63 at 213.

Supra note 13 at 268-269.

lbid. at 269.

Supra note 5 at 724 .

Ibid. 
to be served before eligibility for parole reflects society's condemnation of a person who has exploited a position of power and dominance to the gravest extent possible by murdering the person that he or she is forcibly confining. The punishment is not excessive and clearly does not outrage our standards of decency.

In effect, the judgment states that it is constitutionally acceptable to impose the most severe punishment for the most serious offence. On the most simplistic level, this is intuitively true and its logic cannot be attacked. But on a higher level, it is highly suspect.

Firstly, is reducing s. 12 solely to a question of societal outrage the correct test to apply? This assumes that the community knows the effects of life prison terms, and accepts them as legitimate aspects of our sentencing system." As discussed below, the concerns of the community are usually considered under $\mathrm{s}$. 1. What of the fact that, only a short time ago, the community accepted capital punishment without societal outrage? What of the fact that a large portion of society would support it today?

Secondly, by concentrating on societal outrage, the Court ignores the effects of the duration of the sentence upon the convict, whose s. 12 rights are to be the focus of the analysis. The length of a prison term, and its impact, are clearly part of a proper s. 12 analysis, but no evidence is adduced about the effect on the individual of long term confinement. Although the Court has reminded the legal community that legislation may violate the Charter by reason of either its purpose or its effects, no expert witnesses or empirical material was placed before the Court to explain the effects of the punishment in question. Arguments involving individual rights should not proceed on conceptual grounds, but be assessed in real and human terms. ${ }^{72}$

Third, the idea of a hierarchy of punishments is compelling in the abstract. But what about specifics? Although the analysis supports the imposition of a harsher sentence for first degree murder, it ignores actual sentences. The same reasoning could be used to justify sentences of 50 or 75 years without parole. ${ }^{73}$

Lamer C.J.C. also borrows from Smith the following qualification in regards to s. $12:^{74}$

We should be careful not to stigmatize every disproportionate or excessive sentence as being a constitutional violation, and should leave to the usual sentencing appeal process the task of reviewing the fitness of a sentence. Section 12 will only be infringed where the sentence is so unfit having regard to the offence and the offender as to be grossly disproportionate. In assessing whether a sentence is grossly disproportionate, the court must first consider the gravity of the offence, the personal characteristics of the offender and the particular circumstances of the case in order to determine what range of sentences would have been appropriate to punish, rehabilitate or deter this particular offender or to protect the public from this particular offender.

\footnotetext{
71. Supra note 13 at 269.

72. Ibid.

73. Ibid.

74. Supra note 5 at 724.
} 
But where the discretion of the judge is handcuffed because the sentence is mandatory life imprisonment, with no prospect for parole for 25 years, how can there be any allowance for the Court to consider personal and particular circumstances?

\section{MITIGATING FACTORS}

In the opinion of Lamer C.J.C., Parliament is sensitive to the particular circumstances of each offender through various provisions allowing for the royal prerogative of mercy, the availability of escorted absences from custody for humanitarian and rehabilitative purposes, and for early parole. ${ }^{75}$

The Court had no material before it demonstrating how these extraordinary processes really work. While the prospect of these indulgences does exist, in reality they are rarely used, and are not available to everyone. ${ }^{76}$

The royal prerogative of mercy is available, but is most often used in situations where it has been established that a person was wrongly convicted. The reference to early parole must mean the parole eligibility review under s. 745 of the Criminal Code, ${ }^{77}$ which an inmate can commence after serving at least 15 years in custody. This process only provides a new parole eligibility date, and the process itself typically takes three years to complete. $^{78}$

As a practical reality, the issuance of temporary passes is used very sparingly, principally for funerals or visits to sick relatives. Also, in $R$. v. Shubley, ${ }^{79}$ the Court recognized that the only item truly material to determining the severity of an inmate's punishment is the length of time in prison. Per Cory J., in dissent: ${ }^{80}$

To every inmate the significant portion of the sentence is the time served inside the prison. Imprisonment means the denial of freedom of movement and the segregation or isolation of an inmate from society. That being so, then the real termination of a prison sentence, certainly from the perspective of the inmate, is the moment when he or she is permitted to reintegrate into society. It is that freedom of movement and the ability to interact with others which is so very important to every individual.

Thus, the possibility of access to such bells and whistles as temporary passes cannot be said to be truly relevant in characterization of punishment. If at all, the existence of these mitigating factors would be more relevant to a s. 1 justificatory analysis, and this is where these should have been argued.

lbid. at 725.

Supra note 13 at 270.

am. R.S.C. 1985, c. 27 (2nd Supp.), s. 10.

Supra note 13 at 270.

[1990] 1 S.C.R. 3, 42 Admin. L.R. 118, 104 N.R. 81, 52 C.C.C. (3d) 481, 65 D.L.R. (4th) 193, 37

O.A.C. 63, 71 O.R. (2d) 63, 46 C.R.R. 104 [hereinafter Shubley cited to S.C.R.].

Ibid. at 10 . 
More relevant to a discussion of the legislation's intrusion on individual rights would be the fact, as discussed above, that the existence of the mandatory life sentence created the need to develop the special defence of provocation and other mitigating factors. Is there any good reason for this separate regime of defences? Would the law not be better served by removing fixed penalties altogether and allowing special defences as mitigating factors in imposing sentence? ? $^{81}$

\section{CHOICE OF AUTHORITIES}

Lamer J., as he then was, concluded his reasons in Smith by quoting, with approval, the Canadian Sentencing Commission's recommendation that Parliament keep the minimum sentence for murder and treason. ${ }^{82}$ He does not deal with the opinions of other groups. The Canadian Criminology and Corrections Association is of the opinion that such a long period of imprisonment is inhumane unless absolutely necessary in each individual case, and that such a long period of ineligibility for parole or temporary absence creates a group of particularly dangerous people since they have nothing to lose in escaping or attempting to avoid arrest. ${ }^{83}$

In an era when the prevailing constitutional adjudicative methodology directs judicial consideration to both the purpose and the effect of impugned legislation, it is disappointing that the Court did not follow this path. ${ }^{84}$ With respect, the s. 12 analysis applied by the Court should have dealt with the duration and effect of the time spent by the convict, and not in legitimizing what community standards are presumed to be.

\section{SECTION ONE, BY ANOTHER NAME}

In Luxton, the Court did not find a violation of ss. 7, 9 or 12 of the Charter, but that does not mean $\mathrm{s}$. 1 issues were not litigated. The case continues a serious slide by the Court, first noted in $R$. v. Schmidt, ${ }^{85}$ in the interpretation of the Charter. Concern lies with whether the Court will be able to define the scope and content of protection in each of the Charter provisions without falling into an analysis which concentrates on the objectives of the legislation and their validity and importance to society. ${ }^{86}$

In Luxton, the Court's analysis of the rights infringed by the legislation is peppered with $\mathrm{s} .1$ factors. Considered are: discussions of alternatives to long-term sentencing; procedural safeguards providing sensitivity in individual circumstances; the societal interest in punishing wrongdoers (as quoted above); the other objectives of a system of sentencing; the fundamental purpose of sentencing - the protection of society; and public

\footnotetext{
Supra note 9 at 142.

Supra note 62 at 1081.

Canadian Criminology and Corrections Association, Comments on Bill C-84, 1976 [Ottawa: C.C.C.A., 1976] at 1.

Supra note 13 at 265.

[1987] 1 S.C.R. 500, 58 C.R. (3d) I (sub nom. Schmidt v. R.), 33 C.C.C. (3d) 193, 39 D.L.R. (4th)

18, 28 C.R.R. 280, 20 O.A.C. 161,76 N.R. 12, 61 O.R. (2d) 530.

M. Manning, "Lyons: A One-Stage Approach to the Charter and Undue 'Constitutional Notice'" 61

C.R. (3d) 72 at 72 .
}

86. 
standards of decency in regards to punishment. For example, Lamer C.J.C. states in regard to a s. 7 attack on the sentencing scheme: ${ }^{87}$

There is no doubt that a sentencing scheme must exhibit a proportionality to the seriousness of the offence, or to put it another way, there must be a gradation of punishments according to the malignity of the offences. However, a sentencing scheme also must take into account other factors that are of significance for the societal interest in punishing wrongdoers.

Isn't s. 1 the correct place to determine society's interests? Section 7 is normally where an individual's protections from the legal system are discussed. The principle of interpreting Charter rights in terms of the persons and interests it was designed to protect should not be lost in the quest to rationalize the legislation's existence. Otherwise, the Court would allow Parliament's penal policies to frame the content of the principles of fundamental justice.

Lamer C.J.C. refers heavily to Smith in the course of the s. 12 analysis but overlooks his comment from that case: ${ }^{88}$

If a grossly disproportionate sentence is "prescribed by law," then the purpose which it seeks to attain will fall to be assessed under $\mathrm{s}$. 1. Section 12 ensures that individual offenders receive punishments that are appropriate, or at least not grossly disproportionate, to their particular circumstances, while $\mathbf{s} 1$ permits this right to be overridden to achieve some important societal objective.

Logically applying this, the Court should have concentrated its efforts in the s. 12 analysis on the individual's rights. Any analysis of justification would come later, under s. 1. In failing to discuss the actual protections afforded the individual, the Court reinforces the impression that its concern lies more with justifying s. 231(5) than with submitting the legislation to rigorous constitutional scrutiny.

Consideration of societal effects, by internalizing a proportionality test or valid objective test into the right itself, is bound to give a narrow interpretation to that right, rather than a large and liberal one, loading the right with baggage it was not designed to carry. While this analysis is relevant to the ultimate finding in the case, it is more appropriately done under s. 1, with the Crown bearing the burden of proof. It has no place when defining the scope and content of the legal right itself. ${ }^{89}$

The Court has here defined the scope and extent of legal rights in terms which seek to balance and give effect to societal rights and considerations, similar to the way courts in the United States analyze the content of the American Bill of Rights, although the American legislation has no $\mathrm{s} .1$ saving provision. ${ }^{90}$ Perhaps this suggests too much cross-border borrowing on constitutional adjudicative matters. 
Interpretations of the Charter which limit the right in question by defining its content in terms of societal objectives, or through reference to standards of rationality, smack of a valid federal or legislative objective test, which helped freeze the Canadian Bill of Rights into a lofty set of legal phrases, which aided no one but legal academics. ${ }^{91}$ It is hoped that the Court can strive, as much as possible, to ensure that the Charter rights are given a large and liberal interpretation, and that $s .1$ be the battleground for any and all justifications of infringements on those rights.

\section{WHEN IS HISTORY RELEVANT?}

The tainted origins of s. 231(5) were not argued before the Court. Why not? Possibly because defence counsel have been given mixed messages from jurists on how arguments involving past social and legislative history will be received, where the intent and purpose of an impugned enactment must be deduced.

The Supreme Court of Canada relied heavily on history, albeit not legislative, in Southam Inc. v. Hunter Inc., ${ }^{92}$ in 1984. In R. v. Big M Drug Mart, ${ }^{93}$ Dickson J., as he then was, traced the Lord's Day Act ${ }^{94}$ right back to the Sunday Fair Act, $1448,{ }^{95}$ in concluding that the law was religious and not secular.

However, Lamer C.J.C., as he then was, for the majority of the Court in Reference re s. 94(2), reiterated that the legislative history of any enactment should be given very little weight, as it is "inherently unreliable. ${ }^{196}$ And in $R$. v. Turpin, ${ }^{97}$ the Court suggested that a review of the social and political historical background of legislation would be fruitless. Subsequent litigation has done little to clarify the issue.

Courts constantly have to deal with separating reliable evidence from the unreliable. Where legislative history is relevant, the courts should not dismiss it in a preemptory fashion. Which is the lesser evil: the possibility of having to weigh potentially unreliable evidence, or the necessity of inventing principles to define a Parliamentary intent which never really existed?

In interpreting statutes like the Criminal Code, which are bound to contain some constitutional deadwood, surely evidence as to legislative history can play an enlightening role. Mixed messages, like those outlined, are disturbing. Perhaps a clear, definitive statement on this issue is in order.

\section{Ibid. at 73 .}

92. [1984] 2 S.C.R. 145, 41 C.R. (3d) 97, [1984] 6 W.W.R. 577, 33 Alta L.R. (2d) 193, 27 B.L.R. 297, 84 D.T.C. 6467, 11 D.L.R. (4th) 641, 2 C.P.R. (3d) 1, 9 C.R.R. 355, 55 A.R. 291, 55 N.R. 241,14 C.C.C. (3d) 97 at 107.

93. [1985] 1 S.C.R. 295, [1985] 3 W.W.R. 481, 18 D.L.R. (4th) 321, 18 C.C.C. (3d) 385, 13 C.R.R. 64, 60 A.R. 161, 85 C.L.L.C. 14023, 37 Alta. L.R. (2d) 97, 58 N.R. 81.

94. R.S.C. 1970, c. L-13.

95. 27 Hen. 6, c. 5.

96. Supra note 43 at 314.

97. [1989] 1 S.C.R. 1296, 69 C.R. (3d) 97, 96 N.R. 115, 48 C.C.C. (3d) 8, 34 O.A.C. 115, 39 C.R.R. 306. 


\section{JUDICIAL BATCH PROCESSING}

The six decisions issued September 13, 1990 allow us some insights into the pros and cons of the relatively new practice of the Supreme Court of Canada in hearing several appeals, and releasing several judgments concurrently, on issues of a common theme. There are several potential problems with this practice.

First of all, one presumes that the Supreme Court of Canada developed this practice for the sake of efficiency. This can be questioned, since such consolidation of important cases may spawn greater numbers of intervenors. For instance, in Vaillancourt, only the Attorney General of Ontario appeared as an intervenor. In Martineau, and again in Luxton, the Attorney Generals of Canada, Quebec, Ontario, Manitoba and British Columbia all participated as intervenors, in addition to the respondent Attorney General of Alberta. Therefore one might question the benefits of such a process, from a cost and time standpoint.

Secondly, it is possible that the presence of a large number of intervenors may politicize the Court. The representation of the Attorney Generals was recognized in the judgments of both Lamer C.J.C. ${ }^{89}$ and Sopinka J.9 in the Martineau decision. If judgments of the Court are tailored in response, this might have the effect of forcing arbitrary judicial line drawing, in certain cases, on statements of principle.

Thirdly, it is apparent that facts and individual factors crucial to a given case may be overlooked. This is unlikely since the nature of the appeals were constitutional issues. However, it may affect how counsel prepares for such cases, and how much weight their arguments are given. It may be too easy to dismiss valid arguments made by counsel by simply referring to a concurrent case where a point was not made as cogently or as forcefully.

Certainly, the process of advocacy at the Court has been changed. It is submitted that defence counsel practice must adapt in response, with more communication and cooperation, if they are to represent their clients well in the future against equally well prepared intervenors, acting in legion. This will likely increase the costs of taking an appeal to the Supreme Court of Canada.

\section{WHERE THE COURT DRAWS THE LINE}

In Vaillancourt, the Supreme Court struck down s. 230(d), which had been described as "the harshest murder definition of any civilized country." ${ }^{100}$ In Martineau, the Court attacks s. 230 and s. 229(e) to move to remove entirely objective mens rea for murder. L'Heureux-Dube J., in her dissent, notes in a comparative analysis of the laws of Great Britain, New Zealand, Australia and the United States that no other common law country 
has adopted a totally subjective mens rea for murder. ${ }^{101}$ In other words, in a swing of the pendulum, Canada went from the harshest to the most relaxed murder laws of any country sharing our jurisprudence. The Court may have sensed that any further changes, made solely on principle, would be going too far.

Sopinka J., in Martineau, warned against making overbroad statements of principle inimical to the traditional development of the law. ${ }^{102}$ Recognizing the presence of the Attorneys General as intervenors, he manifested a resolute unwillingness to move the law any further. Perhaps, on a tacit level, the other justices did to.

If this was the case, it is discouraging. With respect to the Court, there is no room for compromise on principle. Scrutiny of such laws is not a usurpation of legislative power, but the will of Parliament as expressly stated in the Charter. The ultimate supremacy of Parliament is still preserved through its power to invoke s. 33 of the Charter, and therefore the Court should not feel the need to invent justifications to describe an intent which Parliament never really had. ${ }^{103}$

\section{EFFECT ON THE LAW}

The decisions handed down by the Supreme Court on September 13,1990 can be seen as a mixed blessing. The Court is to be commended for ridding Canada of the much criticized constructive murder provisions. ${ }^{104}$ The general thesis of this commentary has been that the Court should have been consistent in applying the same logic to s. 231(5).

Only $16 \%$ of all homicides in Canada occur in the course of other offences, and a far smaller number occur in the course of offences listed under s. 231(5). ${ }^{105}$ As mentioned above, only 5 convictions occurred under s. 231(5)(e) [unlawful confinement] in the course of 8 years.

\section{A. POST-LUXTON APPLICATION}

When the Crown attempts to secure a conviction under s. 231(5)(e), it provides a useful example as to the deficiencies of the present Criminal Code. A review of post-Luxton cases indicates the problems implicit in using the rhetoric of an "organizing principle" when not supported by the legislation or its history. An illustration is $R$. v. Strong, ${ }^{106}$ a decision of the Alberta Court of Appeal, in which the Crown sought a conviction of first degree murder, arguing that the murder occurred while the victim was being unlawfully

\footnotetext{
101. Supra note 35 at 666.

102. Ibid. at 685.

103. Supra note 28 at 333.

10. Supra note 3 at 250.

105. Ibid.

106. Supra note 56.
} 
confined in the course of a robbery at his home. The Court, per curiam, states as follows: ${ }^{107}$

\begin{abstract}
It must be observed, of course, that not all offences involving illegal domination of one person by another are included in the list of offences in s. 214(5) [now s. 231(5)]. The notable exception is robbery where the domination of another by force or threats is an element of the offence. The maximum sentence prescribed by Parliament in s. 303 [now s. 344] for robbery is life imprisonment, as compared to 10 years for unlawful confinement. Thus we have in this case the unusual situation that a prosecutor, having proven the commission of a murder, attempts to import into the serious offence of robbery, committed simultaneously, the elements of the less serious offence of unlawful confinement. If the effort is successful, the resulting sentence regime is for first degree murder.
\end{abstract}

The Crown argued, with impeccable logic, that in virtually all robberies, the offender would also be guilty of unlawful confinement, since the victim would be deprived of his or her liberty at some point of time. Since robbery is a crime of specific intent, the Crown is bound to prove, under s. 343 of the Criminal Code, that the accused applied violence with the specific purpose of stealing. Since violence or threatened violence is a requisite element of the offence, every robbery involves some restraint to the victim. Yet the Court, despite recognizing the existence of a "organizing principle" of illegal domination as affirmed in Luxton found it could not classify a murder in the course of a robbery as first degree, since: ${ }^{108}$

Parliament has clearly chosen to omit robbery from the list of offences which reduce that result. It cannot, therefore, have intended that the transitory restraint inherent in the violence or threatened violence of every robbery would trigger the section. That would be to put robbery in the list of offences in s. 214(5) without expressly mentioning it.

Here once again, we see the judicial presumption of the grand vision of an all-seeing and all-knowing Parliament, which is quite a distinction from the heated and partisan debates as recorded in Hansard.

\title{
B. SUMMARY
}

In the view of the Supreme Court of Canada, s. 231(5) is now meaningless except in a small number of cases where intentional killings take place in the course of one of the offences listed. But what of these cases? The fact that a small number of persons are involved creates an even stronger case for closer scrutiny of the first degree murder rule, as it removes any argument that a floodgates effect will occur. The courts will not be overwhelmed by judges applying discretion in the sentencing of a very few individuals. Given the law will affect so few, can we not afford to move to a simpler, completely integrated and principled approach for all our murder laws? 


\section{CONCLUSION}

It is important, where the Criminal Code is being scrutinized against the Charter, that the Supreme Court's decisions are selective and well aimed blows, as that body of law is in need of a general overhaul. Cases must be seen as symptomatic of the need for reform rather than all the reform that is needed. ${ }^{109}$ It is submitted that the decision in Luxton is not well aimed nor well reasoned.

In retrospect, the government of the day was probably correct in the trade-offs made, in offences and sentencing legislation, in order to achieve the success of the abolition movement. ${ }^{110}$ But it must be remembered that the list of offences that automatically trigger first degree murder convictions is the product of a haphazard and expedient debate on the House of Commons floor as part of the price of abolishing the death penalty. ${ }^{\prime \prime \prime}$

Now, over 15 years later, ample time has passed to assess the trade-off in light of the Charter, the rationality and proportionality of sentencing, and hard evidence about the effects of long term confinement. It is saddening to think that the political compromises of 1976 have now become constitutional benchmarks. And it is even more disappointing to find the Supreme Court has sought to make the political bargaining process seem principled. ${ }^{112}$ 